\title{
A USDA Sound Documentary about Southern African American Farmers
}

By J. Emmett Winn

Fall 2015 Issue of KINEMA

This article is available in Print edition of KINEMA

\section{Author Information}

J. Emmett WINN is Professor in the School of Communication and Journalism at Auburn University (Alabama). He is the author of Documenting Racism: African Americans in US Department of Agriculture Documentaries, 1921-42, The American Dream and Contemporary Hollywood Cinema, and co-editor of Transmitting the Past: Historical and Cultural Perspectives on Broadcasting. His scholarly articles have appeared in Critical Studies of Media Communication, The Journal of Broadcasting and Electronic Media, Film and History, among others. 